A N TONIO AR N O N I PRADO

Sérgio Buarque na redação do Diário Carioca, no Rio de Janeiro

ANTONI ARNONI PRADO é professor de Teoria Literária na Unicamp e autor, entre outros, de 1922 -

Itinerário de uma Falsa Vanguarda (Brasiliense)

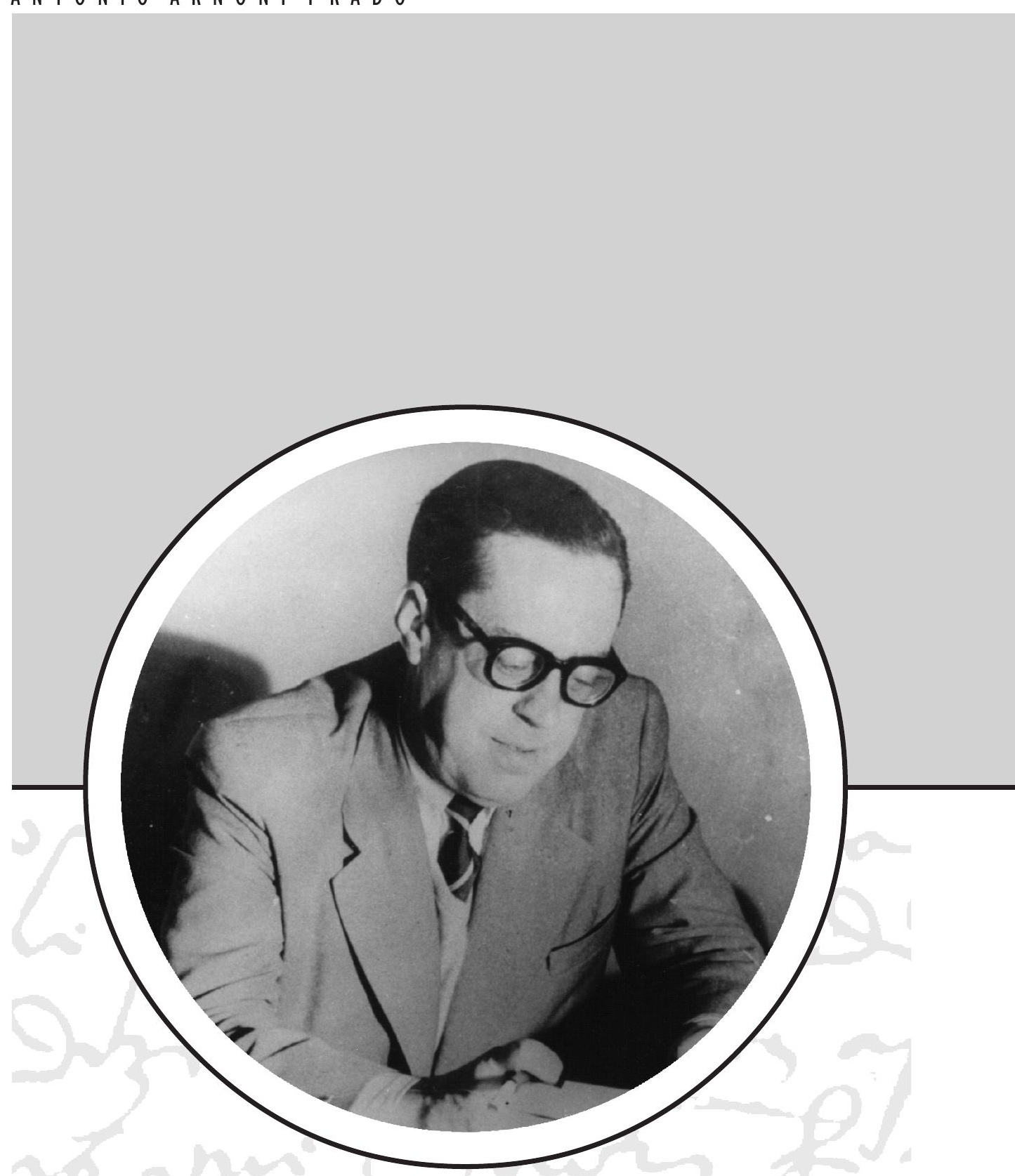

Para d. Masia Amélia Buarque de Holanda 


\section{Uma visita}

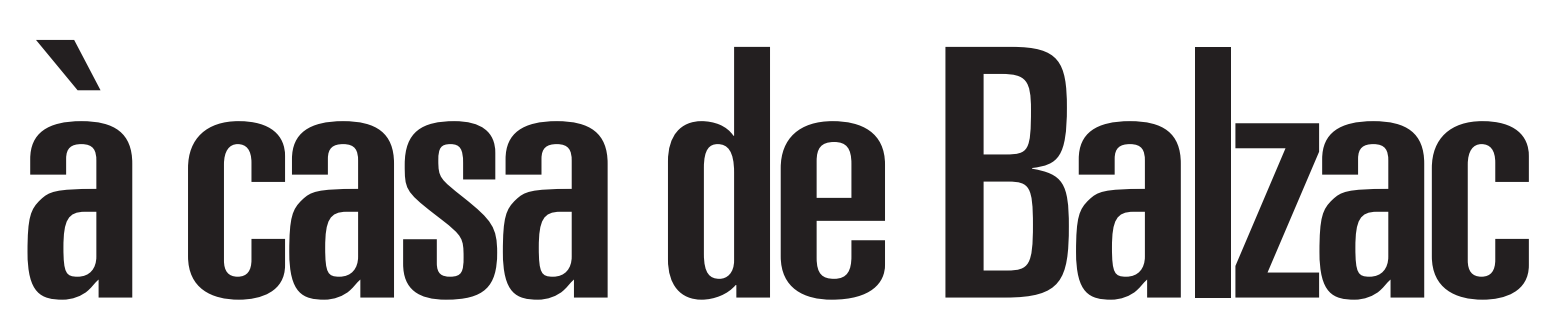

\section{Crônica, memória e}

história na crítica de Sérgiio

Buarque de Holanda 
ma das contribuições mais originais de Sérgio Buarque de Holanda à crítica literária brasileira vem justamente de sua sensibilidade de historiador. Não que, nele, o traço específico da avaliação estética se dilua no conjunto da apreciação dos dados documentais, que entram em suas análises com a precisão de um instrumento de cultura capaz como só ele de dar vida à temporalidade do literário, articulando-a com as experiências difusas no tempo do leitor. Mas particularmente porque, tendo consciência de que o primeiro passo da crítica está na própria elaboração do poético, em cada caso e em cada época, as tarefas que assume em face desse processo aprofundam os reflexos que o produto de semelhante elaboração vai encontrar em seu público e em sua época.

Este o motivo para que em Sérgio Buarque de Holanda a grande função da crítica, e sua legitimação até - como nos explica num de seus estudos recentemente publicados -, esteja "na parcela decisiva com que pode colaborar para esse esforço de recriação [que] dilata no tempo e no espaço um pouco do próprio processo de elaboração poética" (1), constituindo-se numa instância verdadeiramente criadora.

Da perspectiva de Sérgio, na verdade, não há como empreender esse esforço de recriação fora das circunstâncias históricas, sociais ou culturais que correspondem ao instante de criação da obra em si mesma. É com esse intuito que o vemos, num estudo sobre André Gide, ajustar a fisionomia literária do escritor a uma visão de conjunto que "abrange todos os seus aspectos tão vários e discordantes entre si”, sem no entanto deixar de estudar cada um deles isoladamente, com o objetivo de estabelecer a maior harmonia possível, "a maior unidade entre as várias considerações", como faz questão de assinalar (2).

Oefeito que lhe interessa mostrar é o de Sérgio Buarque de Holand "O Mito de Anteu - I", in Antonio Arnoni Prado (ed.) O Espirito e a Letra. Estudos de Crítica Literária, São Paulo, Companhia das Letras, 1996 vol. II, p. 142.

2 Cf. "André Gide", ibidem, vol. I, p. 170 to de que a vitória do individualismo pressupõe, em seu limite, a renúncia à própria individualidade.

O caminho para essa constatação vem, no entanto, pelo estudo harmônico das circunstâncias. Nas suas mãos, os diários, as cartas, a crônica de uma vida ou de uma época, a leitura histórica, ao contrário de meras referências, entram comofundamentos na busca dessa unidade entre o homem que pensa e o homem que sente, de cuja perspectiva procura aproximar-se para compreender as diferentes instâncias que cercam as relações entre o universo da obra e o universo de seus leitores.

Significativa, sob esse aspecto, é a observação de que o texto crítico, a exemplo da análise histórica, inscreve-se, como produto intelectual, entre as expressões de cultura "essencialmente mutáveis que não se convertem sem violência em normas adequadas para todos e para sempre", abrindo assim um outro caminho para avaliar a coexistência entre o espaço da obra e as circunstâncias de época no espaço fora do texto. Interessante, aqui, é ver como o crítico põe em suspensão a regra geral de que os nossos conhecimentos nascem da subordinação do particular ao universal, para reconhecer como historiador "que para certos homens o essencial continua sendo o que há de particular, de milagroso, o elemento irredutível de cada coisa" e concluir - sem que isso comprometa a objetividade da análise - que, quando a ênfase recai nesses homens "que obedecem às leis divinas e esquecem as outras, as das cidades", nem por isso a força com que emergem para a história deixa de situá-los como forças decisivas na conformação da vida.

Será um erro, entretanto, supor que a iluminação desse desvio, por si só, baste para compreender a complexidade de seu alcance. E o modo como ilustrou essa verdade tratando de um livro como Canaã, de Graça Aranha, por exemplo, é um dado expressivo. Para Sérgio, será sempre uma operação arriscada tratar da concepção estética de uma determinada obra separando-a do esforço crítico com que seu autor busca ele mesmo compreendê-la fora do texto. 
Não que a reflexão a posteriori refaça o traçado formal da ficção e reoriente o sentido de sua verdade, mas porque - ao crítico-cabe sobretudo a tarefa de harmonizar as hipóteses do que em princípio parece incongruente e disperso para só então conjecturar as dimensões da verdade latente. Como, sob esse aspecto, entender o plano ficcional do romance de Graça Aranha, em que o narrador aprofunda certos contrastes que mostram bem a precariedade da vida local (o primitivismo das condições de trabalho e da ordem social, o despreparo das autoridades, retratadas por exemplo na ingenuidade do agrimensor Felicíssimo e nas arbitrariedades da Justiça, cujos agentes, como o Pantoja, o dr. Brederodes, o dr. Itapecuru, nada mais refletem que a inaptidão dos nativos para conviver com os códigos da vida organizada), - como entender o arranjo estético desses motivos sem ter em conta - nos lembra Sérgio - a tese do próprio Graça Aranha, segundo a qual o sentimento é indiferente à história e a ausência da tradição equivale a um afortunado privilégio do homem americano, livre para ampliar em seu espírito a pureza da emoção estética e assim prolongá-la ao infinito (3)?

A idéia que o anima é a de que, antes de estudar a produção literária de um escritor, impõe-se estudar o conjunto da sua formação intelectual, vislumbrando nela os pontos de relação com a vida e a cultura do seu tempo, responsáveis - como qualquer instância representativa - pelo diálogo sempre aberto com os produtos estéticos resultantes dessa experiência. Lidos na perspectiva de Graça Aranha, por exemplo, os personagens do conde de Gobineau refletem outras ressonâncias de cultura sem as quais é impossível penetrar na atmosfera ficcional em que se movem. Para compreendê-los, segundo Sérgio, será preciso observar que são originários de um mundo em que a natureza física é uma expansão da natureza moral, e só isso é capaz de explicar a singularidade das emoções e dos sentimentos na alma tanto das personagens quanto de seus leitores. É esse o motivo, nos diz ele citando Gobineau, pelo qual as cenas mais deslumbrantes do Canaã jamais poderão ser avaliadas pelos critérios com que deveremos analisar o espaço de um romance como Les Pléiades, por exemplo.

Isso explica que muitas vezes o próprio esforço crítico fora do texto se transforma em ato criador, valendo-se diretamente da pesquisa historiográfica. Exemplar como traço dessa equivalência é o modo como nos revela, na composição de um episódio de O Tempo e o Vento, de Érico Veríssimo, o uso da pesquisa histórica enquanto matriz da cena literária. Na verdade o que Sérgio nos mostra nessa passagem do romance é que o cenário da velha igreja de São Miguel, no conjunto da descrição das ruínas do povoado dos Sete Povos das Missões, quando para lá vai o doutor Winter, resulta de uma anotação de Érico Veríssimo à pesquisa documental realizada pelo historiador Hemetério Veloso em seu livro As Missões Orientais e seus Antigos Domínios, publicado em Porto Alegre pela tipografia da Livraria Universal de Carlos Echenique, no ano de 1909, no qual pela primeira vez se registra o fato de que a velha torre ainda "conservava interiormente o compartimento de madeira que resguardava o maquinismo do relógio, mas a escada de madeira para lá subir estava, quase toda, desfeita" (4). Retomado na ficção, esse registro do cronista interfere na ação do personagem criado pelo artista, frustrando a sua tentativa de chegar ao alto da torre para conhecer o velho relógio: “os degraus da escada do campanário”, anota o narrador de O Tempo e o Vento, "cederam ao peso de seu corpo e partiram-se" (5). Mas ao mesmo tempo nos revela como uma personagem fictícia interfere, ao ver-se tentada a subir para o alto da torre, na derruição da escada "que uma testemunha real só pôde atestar vinte anos mais tarde", dado que a visita de Hemetério Veloso ao cenário da luta só se daria no decênio de 1850, e o episódio ficcional transcorre nos anos de 1830 (6).

O importante nesse processo, ressalva Sérgio, é que as atividades paralelas do artista e do cronista correm cada uma a seu lado e não perdem a sua autonomia. O texto

\footnotetext{
Ver "Um Homem Essencial", in O Espirito e a Letra, op. cit, vol. I, pp. $|8|$ e segs.

4 Ver Hemetério Veloso, As Missões Orientais e seus Antigos Domínios, p. 246

5 Érico Veríssimo, O Tempo eo Vento, Porto Alegre, Globo, 1950, vol. I, p. 381 .

6 Sérgio Buarque de Holanda O Espírito e a Letra, op. cit. vol. II, p. 23I.
} 
que resulta como produto, no caso um romance, é que exige uma análise combinatória das convergências possíveis, já que não se trata de afirmar a prevalência de um pólo sobre o outro, como aliás ele faz questão de assinalar numa de suas leituras de $O$ Tempo e o Vento: "O cortejo dos fatos históricos está presente a todo momento, mas jamais avança até o primeiro plano para atropelar o conteúdo propriamente romanesco, nem retifica o movimento livre do artista, segundo as leis de um mundo já organizado e de rígidos contornos, para dar-lhe direção prevista e almejada". Ao contrário, "a evocação do passado faz-se sempre por vias indiretas, segundo um sutil e quase invisível processo de seleção" (7).

Na leitura desse intercurso da ficção com a realidade também não cabe, segundo Sérgio Buarque de Holanda, falar em sacrifício de um segmento em favor do outro. É nesse sentido que a verdade dos personagens de Érico Veríssimo se relaciona com o sistema de valores construído no romance e não com os modelos da época a que a obra corresponde. Enem é possível, noutra direção, condicionar a existência dessa obra (ou mesmo do gênero) a um determinado estágio de evolução do contexto histórico que lhe corresponde, como o fez, por exemplo, Lúcia Miguel-Pereira, ao sustentar que o romance só atinge um nível superior de desenvolvimento nas sociedades dotadas de fundas estratificações e de grande densidade espiritual. Moby Dick, de Melville, malgrado o recorte alegórico que o deixa mais próximo do gênero épico que da formação romanesca convencional, é um exemplo-argumenta Sérgio acompanhando o pensamento de Osmar Pimentel na refutação à autora de Prosa de Ficção (1870-1920) - de como as duas perspectivas não perdem a sua integridade nem se sacrificam uma à outra sem prejuízos relevantes para ambas (8).

Como se vê, é paradoxalmente o faro do historiador que, na crítica de Sérgio Buarque de Holanda, contribui para enriquecer a dimensão estética da literatura. Na verdade são os modos com que interroga essa convergência que dão singularida- de a tudo que leu e escreveu enquanto crítico. Num primeiro instante, ao propor um distanciamento na avaliação do processo criativo. Com efeito, não é de dentro da literatura que ele procura, como tantos outros, a relação com a história e nem tampouco é da perspectiva da história que se situa para conceber as suas reflexões literárias. O seu foco, conforme procurou sugerir no referido ensaio sobre Érico Veríssimo, é uma espécie de olho móvel a flutuar sobre o que chamou de paisagem transcendente da obra, aquele plano virtual que não pertence efetivamente ao mundo histórico nem ao mundo da ficção, a dimensão em que nasce e se expande o núcleo da composição, a inteligência central e a moldura da verdade ficcional legitimada como símbolo à parte mas interferindo vivamente nas instâncias da realidade do mundo em que se insere.

Ao circular no tempo, para usar os termos de Antonio Candido, Sérgio transcende essas mediações para ajustá-las àquele plano virtual de onde a crítica literária pode contribuir para recriar os momentos essenciais no processo de composição da obra. No entanto, se a meta é a fisionomia literária, o modo de compreendê-la não deixa nunca de pressupor a análise minuciosa do conjunto das circunstâncias de que depende o seu processo de significação e leitura no tempo e no espaço em que essa obra vai circular.

O rigor desse critério vale mesmo para as composições de gêneros mistos, como é o caso das biografias romanceadas, nas quais Sérgio não deixou de apontar - nas oportunidades em que isso ocorreu - o peso documental excessivo a desfigurar o quadro ficcional projetado. Foi o que fez por exemplo em relação à Vida de Paulo Eiró, de Afonso Schmidt, em que os fatos ligados à sociedade e à época do malogrado dramaturgo paulista, conforme mostrou, acabam hipertrofiados no conjunto das referências históricas que desequilibram a ordem imaginária e caprichosa de onde deveria emergir a vida do poeta e do homem.

Não que as atividades do biógrafo e do romancista se mostrem inconciliáveis. É 
mesmo possível, e Sérgio faz questão de assinalar, que "os movimentos da imaginação possam perfeitamente acomodar-se ao espetáculo da vida e conformar-se à ordem em que foram postas as coisas". Mas isso em princípio não exclui a verdade, considerada do ponto de vista do historiador, de que a perspectiva do biógrafo é em geral uma perspectiva "adstrita a um mundo já organizado, de contornos fixos e rígidos" que não lhe permitem a liberdade necessária para qualquer trabalho de criação (9).

Quando no entanto as perspectivas se harmonizam, a biografia tem muito a nos revelar porque, a exemplo do romance mesmo o de corte realista, nos diz ele-, ela não nasce de uma observação passiva da existência. Caberá ao crítico distinguir nesse caso, antes da especificidade do gênero, as relações do retrato esboçado com a variável das molduras possíveis decorrentes das marcas que lhe ficaram do contato com a vida no mundo que lhe corresponde. $\mathrm{O}$ foco em questão pode não estar - como em geral não está - na reconstrução integral de uma trajetória ou de uma fisionomia, nos diz Sérgio, e sim nos detalhes - o desvio ou a singularidade que projetam um episódio ou uma vida no panorama de toda uma época. "Em uma era que se pretende realista e onde os fatos concretos importam mais que as simples criações" - nos diz ele ao comentar a vida de Fagundes Varela escrita por Edgard Cavalheiro - “a biografia satisfaz essa avidez melhor do que o romance" (10)

Nela o tema é quase tudo e a forma de tratá-lo, ao contrário do romance, é por excelência um ato de intuição criadora em que a imaginação refaz de um novo ângulo o que os fatos já demonstraram. Esse fascínio da irrealidade contra o pano de fundo das realidades esgotadas, predominante nas biografias, exige do crítico um outro olhar, um exercício de identificação subterrânea capaz de localizar nos detalhes e nos desvios os pontos de articulação do conjunto.

Uma forma de avaliar os desdobramentos dessa estratégia é pensar nas diferentes ocasiões em que Sérgio se valeu da busca quase metodológica desses “setores subjacentes invisíveis a olho nu" para formular o argumento de suas análises. Assim é, por exemplo, que o vemos vasculhar a correspondência de Ezra Pound em busca dos pormenores de uma teoria estética que o poeta só transmitiu aos amigos mais próximos e cujo levantamento, transformado em instrumento crítico, permite a Sérgio fundamentar na obra de Pound a admiração pedagógica pelo gosto do artesanato literário, a presença de ritmos, de melodias e de concepções herdadas de contatos com a poesia de Dante e dos provençais, além de uma vinculação estratégica com o experimentalismo que se instalara na França a partir de 1830 (11).

Com o mesmo empenho é que vai buscar nos diários de Kafka os argumentos para confirmar sua tese de que o pensamento dominante na obra desse autor refoge "a qualquer interpretação que procure associar-lhe um sentido coerente ou uma formulação sistemática". Para a crítica de Sérgio, a singularidade de Kafka, mais que um motivo recorrente na lógica de sua narrativa, é a expansão de um efeito moral deliberado. Por isso, antes dos personagens e das novelas, o seu interesse se inclina para as confissões do homem: "O que tenho eu de comum com os judeus?" é uma pergunta de 1914 que Sérgio retira do terreno da biografia para transformá-la num efeito crítico decisivo para a elucidação da obra, cuja interpretação, para andar próxima de Kafka, deve levar em conta que no universo desse autor a liberdade do homem livre, por exemplo, é mais difícil de suportar do que a prisão do prisioneiro: “Mal poderei dizer que tenha alguma coisa em comum comigo mesmo, e deveria ficar quieto no meu canto, satisfeito de poder respirar" (12).

Outras vezes nos mostra que, nos depoimentos do homem o crítico pode descobrir um procedimento de leitura que, mesmo fora do texto, a ele se associa enquanto instância subsidiária indispensável. Um bom exemplo desse recurso está no interesse de Sérgio em buscar numa carta de Marcel Proust a René Blum, de 1913, a ressalva pela qual o autor da Recherche, explicando a composição complexa de sua
"A Vida de Paulo Eiró", ibidem, vol. l.

10 "Fagundes Varela", ibidem, vol. I

I V Ver a respeito: "O Caso Pound", ibidem, vol. Il, p. 286

12 Cf. Franz Kakfa, Diaries (1914-1923), edição de Max Brod, trad. de Martin Greenberg em colaboração com Hannah Arendt, Nova York, Shoken Brooks, 1965 P.।I; apud "Kafkiana - II", in O Espírito e a Letra, op. cit. vol II, p. 548 
narrativa, revela o temor de que nenhum crítico viesse a compreendê-la. Através dela ficamos sabendo que o que pode parecer uma passagem inútil no primeiro volume tomado isoladamente se constitui - quando relido como recordação nos volumes seguintes - num suporte imprescindível ao plano geral da composição da obra (13).

Mas há casos em que Sérgio discute a natureza da oposição entre os elementos externos e a configuração da própria estrutura da obra literária, procurando ressalvar - no terreno das distinções puramente teóricas - o perigo que os juízos de valor podem representar quando desconsideram o caráter essencialmente ambíguo da criação literária. Nesse passo, por mais que a crítica tenha elementos para elucidar, por exemplo, o contexto moral de uma obra de ficção, será sempre uma redução perigosa subordinar o nível artístico da construção literária à legitimidade dos valores em jogo.

Para quem, como ele, já rechaçara um argumento de Afrânio Coutinho, segundo o qual o valor literário dos romances de Machado de Assis não se livra da contradição moral de que, neles, ninguém trabalha, uma atitude crítica como a de François Mauriac, que relativiza a qualidade estética da ficção de Jean Genet em razão do fundo pecaminoso e diabólico que ela pode veicular, é tema que merece todo o cuidado.

Embora reconheça, como deixou explícito, a dificuldade "de falar com critério sereno de uma obra onde qualidades exemplares de estilo e expressão foram postas tão indiscretamente a serviço do mal", o que Sérgio recusa na crítica de Mauriac é justamente a decisão de atrelar a magia verbal dos textos de Genet à difusão dos temas que repugnam à sua confissão cristã, transformando-os, assim, em instrumentos duplamente condenáveis, porque "podem somar o prestígio da forma ao outro, do vício e da perdição" (14).

O caminho para o impasse pode estar, segundo sugere, em avaliar na singularidade da forma os reflexos de uma outra singularidade, a singularidade que the corresponde no plano da experiência individual inigualável que, segundo Sérgio, move-se no avesso da moral cotidiana e consagrada, um raro exemplo em que a inversão física encontra sua perfeita réplica na inversão dos valores que o passado recusou.

A elucidação pelo contexto, no entanto, pode subir para o primeiro plano da análise quando, numa direção oposta, o argumento da ficção interrompe o curso do tempo para sugerir uma outra forma de ordenação, a da expressão convulsiva dos temas essenciais que compõem a nossa existência, de que é exemplo, a seu ver, a obra de Thomas Hardy. Para compreender a importância de Hardy, ele sugere que o crítico a isole do conjunto das forças ordenadoras de sua época e a tome como um daqueles sintomas de cultura em que "é preciso que o curso do tempo se interrompa para que se possa pressentir o inefável". Não se trata aqui, como no caso de Jean Genet, de avaliar a forma da perspectiva do mal, mas de tomá-la como expansão de uma hipótese que desmantela os códigos vigentes como naqueles momentos de visão que, segundo Sérgio, "só respiram fora da História, à margem da sucessão do tempo". Nesses momentos, nos dirá ele, "todas as forças ordenadoras são sacrificadas e aparece então, nitidamente, a inanidade das polícias humanas e divinas" (15).

Sérgio nos revela em Hardy o que Auerbach nos mostra ao falar de Stendhal, ou seja: interessa-lhe em Hardy o modo como o narrador, sem cair no perspectivismo histórico dos românticos, apreende o cotidiano e desmonta as suas engrenagens, construindo a fisionomia individual de cada ambiente sem nenhum plano preconcebido para dar conta dos fatores gerais que organizam a vida social. O momento revelador em Hardy, como no Stendhal de Na Mansão de la Mole, está no poder avassalador da intriga, que desenvolve a estrutura da ação sem se valer das forças históricas que lhe servem de base. Auerbach, resumindo o método de Stendhal, nos diz que, neste, a representaçãoé muito mais o produto de uma "analyse du coeur humain" do que propriamente a figuração deliberada dos motivos históri- 
cos que a determinam.

A ela se deve, nos diz ele, a adoção do prosaico na moderna ficção e, com este, a ampliação da instância cognitiva da literatura, que passa a neutralizar o peso documental dos outros discursos. "A possibilidade de recorrer-se ao sermo humilis ou remissus para temas graves e trágicos", explica, "é uma conquista ou antes reconquista do século XIX, que Auerbach acompanha até as últimas consequiências quando aborda a arte de um Proust, de um Joyce, de uma Virgínia Woolf” (16) e que Sérgio pressentia - ressalvemos - já em 1928 ao separar os motivos dos personagens de Thomas Hardy do mundo em que se moviam para assim explicar que na ficção desse autor os homens é que estabelecem as categorias e as oposições entre as coisas, forjando recompensas para os virtuosos e estabelecendo castigos para os ímpios. Nesse universo, que só a instância rebaixada pode nos revelar, tudo nos ensina que o sucesso ou o insucesso ocorrem indistintamente para os bons e para os maus, dado que as coisas não foram arrumadas, "ao gosto dos homens, como num tabuleiro de xadrez. A injustiça", adverte ele, "faz-se lei contra todas as conveniências" (17).

No plano oposto ao dessas cogitações, aparecem as relações materiais entre os fatos históricos e a produção intelectual, cujo significado entra na crítica de Sérgio Buarque de Holanda como um elemento fundamental, mas anterior ao trabalho de análise. Às vezes entra mesmo como simples estudo de relação, como no artigo dedicado às condições favoráveis com que o povoado de Itaboraí, graças ao impulso extraordinário que ali tomou a cultura do café ainda antes de sua elevação à categoria de vila, contribuiu para o desenvolvimento da carreira teatral do jovem João Caetano dos Santos. Eestá presente, com o mesmo sentido, na grande maioria dos estudos e ensaios que escreveu, por exemplo, acerca do modernismo e dos modernistas, pensando, entre outros temas, no predomínio do conto e do relato curto, ao lado da poesia, numa época em que o conjunto da produção literária conviveu com a acelera- ção do tempo social e a fragmentação dos espaços urbanos. Por esse viés, viu bem cedo muita coisa no arranjo inovador dos romances modernistas de Oswald de Andrade, na poesia paulistana de Mário, nos contos e relatos de Alcântara Machado, para não falar na poesia do olhar anônimo que passa e se perde nos flagrantes urbanos de um Manuel Bandeira e de um Carlos Drummond de Andrade.

Os efeitos que o crítico tira dessas circunstâncias em nada diferem - na avaliação do conjunto - das "correspondências" literárias com que o historiador procura ilustrar em cada época e em cada sociedade a repercussão dos fatos e das empresas humanas. A partir de uma referência aos mercadores onzeneiros de começos do século XVII, documentada por exemplo nos Diálogos das Grandezas do Brasil, Sérgio nos revela o fato histórico da assimilação dos cristãos novos na América junto às famílias mais abastadas da colônia. E mostra também, socorrendo-se da mesma fonte, que era comum os demais povos europeus daquele tempo confundirem o português com o judeu.

A referência que a princípio parece apenas documental, desdobra-se para o âmbito da cultura e nesse exercício o crítico socorre-se de personagens e cenas literárias que confirmam, em registro mais amplo, o fato de que "a nacionalidade, mesmo desacompanhada do adjetivo judeu, pode referir-se aos fiéis da Toura", como o revelam, por exemplo, a ladinice de um pícaro como Estebanillo Gonzáles, as associações entre judeu e português lacrimoso presentes na "Visita de los Chistes", de Quevedo, ou nas "Quinas de Portugal", de Tirso de Molina, para não falar na plangência descomedida das elegias de Leone Ebreo, o Jehudah Abarbanel (18).

O mesmo se diga das predileções muçulmanas que marcaram como nenhum outro a figura do rei d. Manuel, segundo dados que Sérgio levanta a partir da História da Sociedade Portuguesa no Século XV, de Costa Lobo. Levanta para ampliar depois, é bom que se diga, mobilizando uma intuição inigualável que persegue os ecos

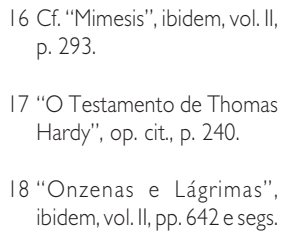


19 Cf. "Doce Baylo de Mourisca", ibidem, vol. II, pp. 638-4I.

20 Ver "Non Placet Hispania", ibidem, vol. II, pp. 634 e segs.

\section{Sérgio Buarque}

aos nove anos de

idade

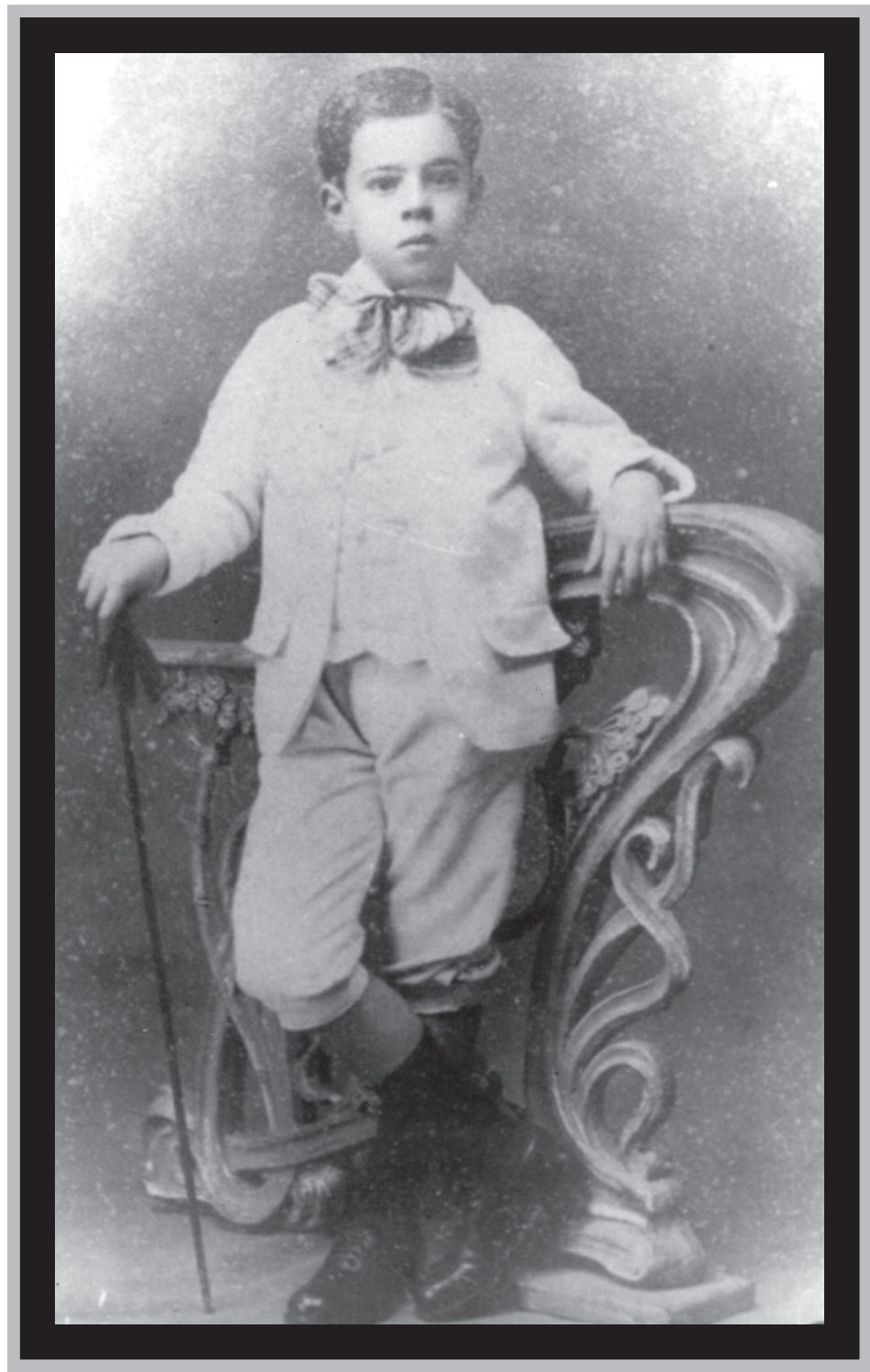
çado um certo Diogo de Pedrosa, impressionado pelos “dengues de uma dança moura" que testemunhou nos movimentos de uma formosa bailarina por quem se apaixona, filha de Fernão da Silveira, coudel-mor na época de João II. É o próprio pai, contrariado com o romance, que confirma a intuição certeira do crítico, desabafando-se nos versos: da música mourisca em diferentes episódios da Crônica do Felicíssimo Rei d. Manuel, de Damião de Góis, assim como nas composições poéticas recolhidas no Cancioneiro Geral de Garcia de Rezende,vai buscar, num episódio evocado em redondilhas, o mal de amor em que caiu enfeitimentos no quadro das referências históricas em que se circunscrevem. Sérgio sobe, para interpretá-los, às hesitações de Dante, perplexo ante a linguagem dos hispânicos (“Que língua falam os espanhóis?"), vai às constatações mais corrosivas de Boccaccio ("Hispanni semibarbari et efferati homines") e aos retratos menos implacáveis dos ragguàgli de Trajano Boccalini, em que os espanhóis aparecem como "uomini tanto nuovi in questo mondo e poco fa usciti dalla crudel servitù dei Mori" (20).

É no espaço dessas convergências que o crítico interroga a coexistência da obra literária com os temas e motivos que a circundam para daí mergulhar na paisagem transcendente a que remetem semelhantes realizações do espírito humano. Esse ângulo de entrada, na verdade uma simulação virtual na paisagen da cultura, não pertence, contudo, nem ao plano histórico nem ao plano da imaginação: é uma aventura de prospecções e vivências. Nela, configura-se uma espécie de permanência que transcende o gênero, diversificado entre as linguagens harmônicas que permeiam o território da crítica, entre elas a do ensaio histórico, a dos registros das memórias, a dos diários, bem como as da crônica e da reportagem literária.

A conseqüência é que, na crítica de 
Sérgio Buarque de Holanda, os resultados de um ensaio erudito sobre Proust, por exemplo, aparecem no mesmo plano das impressões de uma crônica de circunstância, na perspectiva de que, em ambos, as correlações entre o literário e o seu contexto vão sendo gradualmente projetadas como referências da figuração distanciada em que se constrói o universo imaginário do autor e a organização material da obra em si mesma.

Assimé que, para a sensibilidade de um leitor de Balzac, por exemplo, os efeitos de uma crônica de 1949, escrita por ocasião da visita que Sérgio fez à casa em que viveu o autor do Père Goriot de 1840 a 1847, têm um poder revelador equiparável ao das leituras em que a visão crítica se expande para os níveis mais fundos da estrutura da obra. No olhar com que ele percorre a velha habitação da rua Raynouard 47, o que parecia uma incursão momentânea tocada pela curiosidade biográfica desfaz-se logo num horizonte mais amplo: o do temor de que, com as comemorações do centenário de morte do escritor no ano de 1950, a prometida fundação de um Museu Balzac destruísse tudo o que ainda restava da atmosfera onde havia transcorrido a vida íntima do autor da Comédia Humana.

Enquanto observa os inúmeros retratos do autor estampados nas paredes, Sérgio perscruta em cada um deles as marcas deixadas pelo cotidiano insuportável que teve de enfrentar como membro deserdado daquela sociedade surgida das cinzas do Antigo Regime. De repente, é como se deixássemos a casa e nos víssemos em meio às incertezas e aflições materiais que marcaram aquele momento da história francesa, a ponto de um crítico como Ramón Fernandez, grande intérprete da obra de Balzac, afirmar que "pela primeira vez na história da literatura, o destino do homem e sua condição se traduzem em termos de protestos e de letras escritas e assinadas confusamente: a falência é o inferno de Balzac assim como as dificuldades monetárias são o seu purgatório" (21).

De volta aos retratos, compreendemos melhor o sentido que o visitante extrai das imagens que passa em revista, em especial quando se refere às frustrações e às incertezas, além dos sonhos não conquistados. A habitação vai se integrando à atmosfera opressiva que vem da memória histórica para o espaço da cena e a referência à casa como refúgio indispensável à produção da obra e à garantia da própria sobrevivência como que se completa na imagem do alçapão pelo qual Balzac costumava ganhar a rua sempre que descoberto e perseguido "por algum credor mais renitente".

Mas não é só. Recuperadas no tempo histórico, as aflições da atmosfera da casa logo se transmitem para a atmosfera da obra. Não por coincidência Cousine Bette (1846) e Cousin Pons (1847) - lembra-nos ele - foram concebidos e escritos sob aquelas paredes, e uma das caricaturas do romancista ali expostas - que Sérgio enriquece com uma afirmação de Champfleury, segundo o qual se trata do único retrato vivo de Balzac - revela-nos a fisionomia que se abre numa imensa gargalhada, submetendo ao humor e à irreverência o que até então parecia apenas o produto de uma imaginação trágica cujos desfechos não passavam de sombras fugidias e necessárias de um grande painel.

Um breve giro no olhar e a imaginação do cronista nos põe diante de alguns temas biográficos decisivos para organizar uma leitura crítica procedente. Mais do que uma crônica de saudade, é uma reflexão sobre a ausência que só a memória pode recompor.

$\mathrm{E}$ aqui, como o leitor pôde notar, o mergulho no tempo é uma questão prioritária para chegar aos pormenores da obra e da própria imagem do homem. Ou nas palavras do próprio Sérgio: "por menos que se queira acentuar a importância do pormenor biográfico na elaboração de uma obra literária, é impossível, no caso de Balzac, não tentar associar de algum modo à ascendência alcançada em sua vida pelas preocupações monetárias o decisivo papel que elas desempenham em seus livros" (22).
21 "A Casa de Balzac", ibidem,
vol. II, pp. I I0-I.

22 Idem, ibidem 